\title{
Application of $\mu$-Raman spectroscopy to the study of the corrosion products of archaeological coins
}

\author{
Tilde de Caro' ${ }^{1}$, Emma Angelini², Leila Es Sebar ${ }^{2}$ \\ ${ }^{1}$ Istituto per lo Studio dei Materiali Nanostrutturati - National Research Council (ISMN-CNR), Rome, Italy \\ 2 Dipartimento di Scienza Applicata e Tecnologia (DISAT), Politecnico di Torino, Torino, Italy
}

\begin{abstract}
In this paper, a study of the corrosion products formed on archaeological bronze artefacts excavated in Tharros (Sardinia, Italy) is presented. The investigation was carried out by means of the combination of different analytical techniques, including optical microscopy, micro-Raman spectroscopy ( $\mu$-RS), scanning electron microscopy coupled with energy dispersive X-ray spectroscopy and X-ray diffraction. The artefacts under study are three bronze coins from the Phoenician-Punic period that are deeply corroded due to the chloride-rich soil of the Tharros excavation site. $\mu$-Raman spectroscopy was chosen to investigate the corroded surfaces of the artefacts because it is a non-destructive technique, it has high spatial resolution, and it makes it possible to discriminate between polymorphs and correlate colour and chemical composition. Through $\mu$-RS, it was possible to identify different mineralogical phases and different polymorphs, such as cuprite $\left(\mathrm{Cu}_{2} \mathrm{O}\right)$, copper trihydroxychloride $\left[\mathrm{Cu}_{2} \mathrm{Cl}(\mathrm{OH})_{3}\right]$ polymorphs, hydroxy lead chloride laurionite $[\mathrm{PbCl}(\mathrm{OH})]$ and calcium carbonate polymorph aragonite. The experimental findings highlight that micro-Raman spectroscopy can be used to provide further knowledge regarding the environmental factors that may cause the degradation of archaeological bronzes in soil.
\end{abstract}

Section: RESEARCH PAPER

Keywords: Raman spectroscopy; bronze disease; corrosion, cultural heritage.

Citation: Tilde de Caro, Leila Es Sebar, Emma Angelini, Application of $\mu$-Raman spectroscopy to the study of the corrosion products of archaeological coins, Acta IMEKO, vol. 10, no. 1, article 31, March 2021, identifier: IMEKO-ACTA-10 (2021)-01-31

Editor: Ioan Tudosa, University of Sannio, Italy

Received May 25, 2020; In final form November 10, 2020; Published March 2021

Copyright: This is an open-access article distributed under the terms of the Creative Commons Attribution 3.0 License, which permits unrestricted use, distribution, and reproduction in any medium, provided the original author and source are credited.

Corresponding author: Tilde de Caro, e-mail: tilde.decaro@cnr.it

\section{INTRODUCTION}

In the past few decades, a series of cutting-edge analytical techniques have found an ever-growing application in the cultural heritage conservation field, offering interesting insights into the provenance, history and fabrication methods of cultural heritage artefacts. Among these techniques, Raman spectroscopy has become a fundamental tool in conservation science, as it does not require sampling of the artefact under study and the analysis can be performed in museum galleries, storage facilities and conservation laboratories thanks to the use of portable instrumentation [1], [2].

The Raman effect provides a quick and relatively straightforward molecular identification of a material under examination. A Raman spectrum is something like a fingerprint that can be used to identify compounds against a database of standard spectra [3].
This paper deals with the application of micro-Raman spectroscopy ( $\mu$-RS) for the analysis of the corrosion products of some metallic artefacts. $\mu$-RS furnishes an identification of the corrosion products by determining the vibration modes and thus the bond vibrations in the structure [4].

Micro-Raman spectroscopy can be used to identify the mineralogical nature of micro-phases and discriminate between different polymorphs present in the corrosion products of the patina [5]. Furthermore, $\mu$-RS has the advantage of being a fast and non-destructive technique, and, in backscattering geometry, it is especially suitable for analysing surfaces.

Due to its interesting features, $\mu$-RS in addition to other techniques such as X-ray diffraction (XRD) and scanning electron microscopy coupled with energy dispersive X-ray spectroscopy (SEM-EDS) was utilised in order to investigate the chemical and structural nature of the corrosion products (i.e. the patina) grown on archaeological bronze artefacts. In particular, three unreadable coins from the Phoenician-Punic period taken from the Tharros excavation site were studied. 


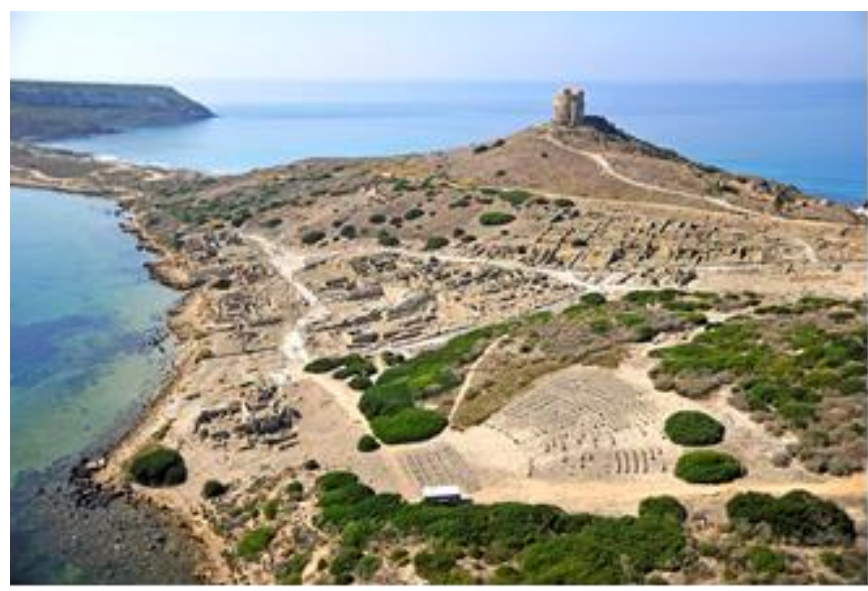

Figure 1. The archaeological site of Tharros (Sardinia, Italy).

The ancient city of Tharros is located along the north-western coast of Sardinia (Italy) and was first established in the Nuragic period. It is currently an archaeological site near the village of San Giovanni di Sinis, municipality of Cabras, in the province of Oristano. It is located on the southern shore of the Sinis peninsula, which forms the northern cape of the Bay of Oristano, as shown in Figure 1. The Phoenicians populated the area during the $8^{\text {th }}$ century $\mathrm{BC}$, and then the city was governed by Carthaginians until the Roman conquest in the $3^{\text {rd }}$ century BC [5], [6]. The remains of the town include foundations of temples, Roman baths, a Roman Castellum Acquae, a Phoenician-Punic tophet and an artisan quarter. The town was the capital of the Judicate of Arborea until around $1070 \mathrm{AD}$, when it was abandoned in favour of Oristano under the pressure of the Arab incursions.

During archaeological excavations carried out in Tharros, a large amount of Punic, Roman and Carthaginian bronze artefacts, such as coins, nails, rings and everyday tools, was found [7]. Due to the length of time they had been buried in the soil, most of the bronze artefacts were covered by a thick layer of corrosion products containing chlorides and were affected by bronze disease, an irreversible and nearly inexorable corrosion process that occurs when chlorides come into contact with bronze or other copper-based alloys. The degradation process induced by bronze disease is cyclic and self-sustaining and destroys the artefacts, transforming them into a greenish powder [8]-[10].

The main purpose of this study was to characterise, by means of a multi-analytical approach, the three coins shown in Figure 2, in order to identify the corrosion products, to ascertain the actual state of conservation and provide recommendations for the selection of tailored conservation approaches [11] and to recommend materials to inhibit the degradation phenomena.

In Section 2, the different analytical techniques are presented. In particular, optical microscopy (OM) and SEM-EDS were employed in order to investigate both the morphology of the corrosion products and their elemental composition. This combination provides the best results for the characterisation of corrosion layers on ancient metal objects and is valid for corrosion layers with thicknesses in the order of micrometres or more.

Micro-Raman spectroscopy was performed to identify the main corrosion products present on the surfaces; it has high spatial resolution, and it can be used to discriminate between polymorphs and to correlate colour and chemical composition [10].

Finally, XRD was carried out to determine micro-structural identification of the crystalline phases and to provide complementary information with respect to the previous techniques.

In Section 3, the results of the performed analyses are reported and discussed. Finally, the conclusion section presents the major contributions of this study.

\section{INSTRUMENTS AND METHODS}

The study of the corrosion mechanisms and the characterisation of the layers of corrosion products on the coins were mainly performed by means of $\mu$-RS, which proved to be a powerful technique for the identification of the different corrosion products.

In the study of corrosion, $\mu$-RS is widely employed to assess the composition of corrosion products in a non-destructive way. A monochromatic light, usually from a laser in the visible range, is employed to determine the vibration mode of the molecules and identify them based on the shift in energy.

Micro-Raman analyses were performed at room temperature using a Renishaw RM2000 equipped with a Peltier-cooled charge-coupled device camera in conjunction with a Leica optical microscope with $10 \times, 20 \times, 50 \times$ and $100 \times$ objectives. Measurements were performed using the $50 \times$ objective (laser spot diameter of about $1 \mu \mathrm{m}$ ) and the $785 \mathrm{~nm}$ line of a laser diode. Two edge filters blocked the Rayleigh-scattered light below $100 \mathrm{~cm}^{-1}$. For this reason, the study of ultra-low wavenumber Raman spectra in the region $<100 \mathrm{~cm}^{-1}$ is overlooked. In order to avoid damaging the patina and to prevent the fluorescence from covering the Raman signal, the laser power was lowered. No baseline was subtracted from the recorded spectra. The spectra obtained were compared with GRAMS spectroscopy software and databases available in the literature [12].

Moreover, an investigation of the chemical composition and morphology of the corrosion product layers was carried out by optical and electron microscopy and X-ray diffraction.

An optical microscope uses visible light and a system of lenses to generate magnified images. OM measurements can be easily performed without any sampling and can be used to study the morphology and distribution of corrosion products on the artefact surface, allowing for identification based on colour.

SEM uses a beam of accelerated electrons to scan an object's surface and obtain higher magnification images. Generally, the microscope is coupled with EDS, which makes it possible to obtain information on the chemical composition of the sample. EDS characterisation capabilities are due to the fundamental principle that each element has a unique atomic structure that appears as a unique set of peaks on its electromagnetic emission spectrum.
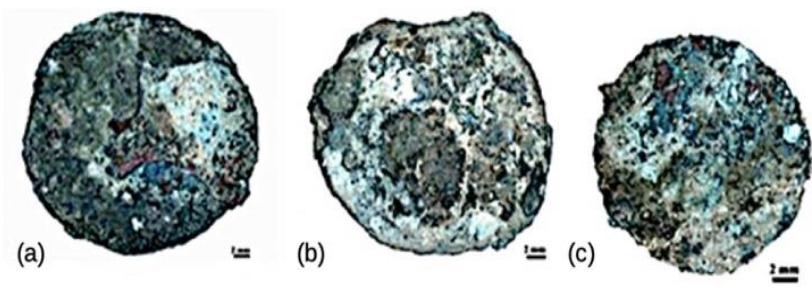

Figure 2. The Phoenician-Punic coins under study found in the archaeological site of Tharros (Sardinia, Italy): (a) THT CLO1; (b) THT CLO2; (c) THT CLO3. 

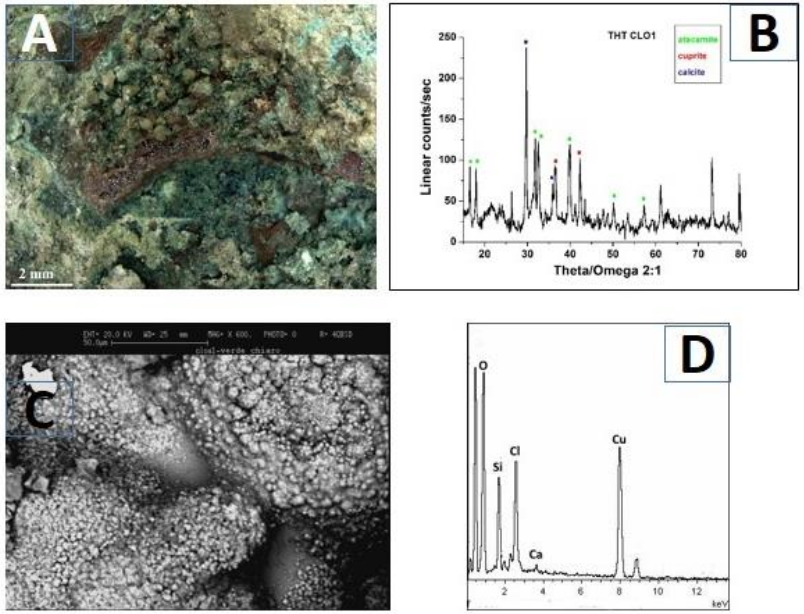

Figure 3. Coin THT CLO1: OM image (A), XRD spectrum (B), SEM image (C) and EDS spectrum (D).

Optical microscopy investigations were performed using a Leica microscope M 125C equipped with a digital camera. SEM and EDS were carried out by a Cambridge 360 scanning electron microscope equipped with a LaB6 filament and with an INCA 250 energy-dispersive spectrometer and a four-quadrant backscattered electron detector (BSE). SEM images were recorded in BSE mode at an acceleration voltage of $20 \mathrm{kV}$ and a working distance of $25 \mathrm{~mm}$.

Micro-structural identification of the crystalline phases formed on the bronze coins was determined by XRD analysis by means of a Siemens $5000 \mathrm{X}$-ray powder diffractometer using Nifiltered $\mathrm{Cu} \mathrm{K} \alpha$ radiation ( $\lambda 1.5418 \AA$ ). Angular values in the range of $20^{\circ}-60^{\circ}$ in additive mode, a step size of $0.05^{\circ}$ and a sampling time of $2 \mathrm{~s}$ were the experimental parameters used for first data acquisition.

\section{RESULTS AND DISCUSSION}

The three Phoenician-Punic bronze coins selected for this study, whose visual appearance is shown in Figure 2, were found in a sewer of the archaeological site of Tharros. The coins, identified as THT CLO1, THT CLO2 and THT CLO3, appeared to be poorly conserved and were analysed before any cleaning or preservation treatment.
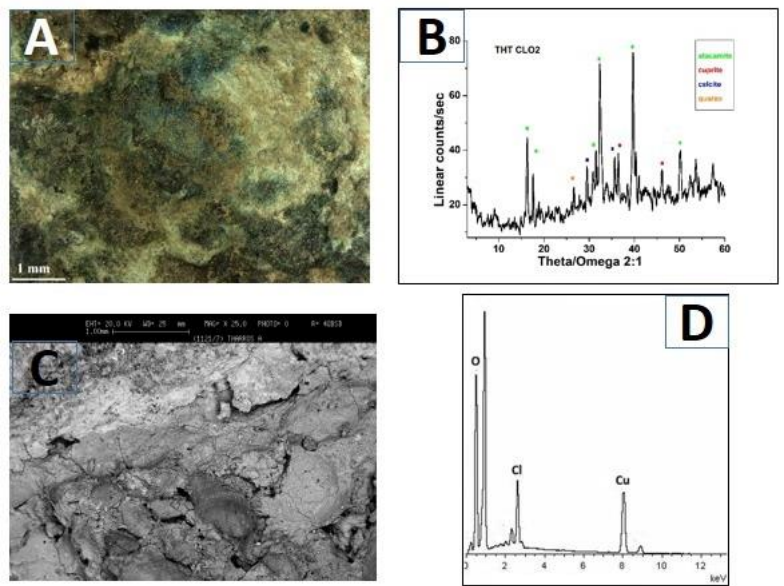

Figure 4. Coin THT CLO2: OM image (A), XRD spectrum (B), SEM image (C) and EDS spectrum (D).
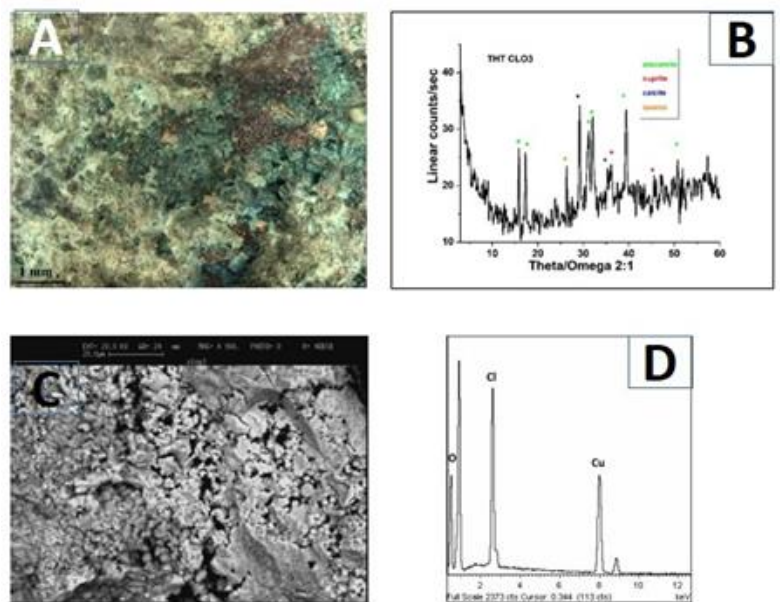

Figure 5. Coin THT CLO3: OM image (A), XRD spectrum (B), SEM image (C) and EDS spectrum (D).

Copper-based alloys are more vulnerable to attack by chloride compared to other corrosive species, especially when they are exposed to marine or coastal environments or buried in chlorideenriched soils. This is the situation experienced by the metallic artefacts from Tharros. Artefacts are mainly endangered by bronze disease when pitting corrosion develops in conditions of high relative humidity and chloride supply. Moreover, phase segregation phenomena contribute to surface heterogeneity and induce local galvanic cells.

At visual examination, the surface patinas of all the coins appear greenish and dusty, as shown in the OM images of Figure 3 , Figure 4 and Figure 5, where the SEM images accompanied by the energy-dispersive spectra and the XDR diffractograms are also reported. EDS spectra reveal the presence of oxygen, copper and chlorine on the coins' surfaces [13].

The XRD spectra of the patinas of the three archaeological artefacts highlight the presence of dangerous copper-containing corrosion products such as trihydroxychlorides $\left[\mathrm{Cu}_{2} \mathrm{Cl}(\mathrm{OH})_{3}\right]$ [13]-[16].

Furthermore, the OM images show the presence of red ruby crystals that can be attributed to cuprite crystals mixed with a small amount of soil components and other corrosion products [16]. XRD spectra confirm the presence of cuprite $\left(\mathrm{Cu}_{2} \mathrm{O}\right)$ mixed with small amounts of soil components including quartz $\left(\mathrm{SiO}_{2}\right)$ and calcite $\left(\mathrm{CaCO}_{3}\right)$.

After these characterisations, the coins' patinas were analysed by means of $\mu$-Raman spectroscopy [16]-[18]. As evidenced in Figure 6, the spectra confirm that the main aggressive agent is represented by chloride-containing species, which lead to the formation of copper chloride- and oxy-chloride-based corrosion products. The Raman spectra allow differentiation between two different polymorphs of $\left[\mathrm{Cu}_{2} \mathrm{Cl}(\mathrm{OH})_{3}\right]$ : clinoatacamite and atacamite [19]. The spectra of these two mineralogical species are very similar: the region where the difference can be observed is highlighted by a red line, while the vibrational assignments are listed in Table 1.

As explained above, bronze disease is a cyclic reaction that occurs when the archaeological artefact interacts with chlorides in the soil that, in the presence of moisture, produce light green powdery copper chloride [nantokite $(\mathrm{CuCl})$ and hydroxychlorides (atacamite and its polymorph clinoatacamite) [20]. The outermost green layer can be constituted by atacamite and its polymorphs, botallackite and clinoatacamite. Thermodynamic data show that clinoatacamite is the most stable 


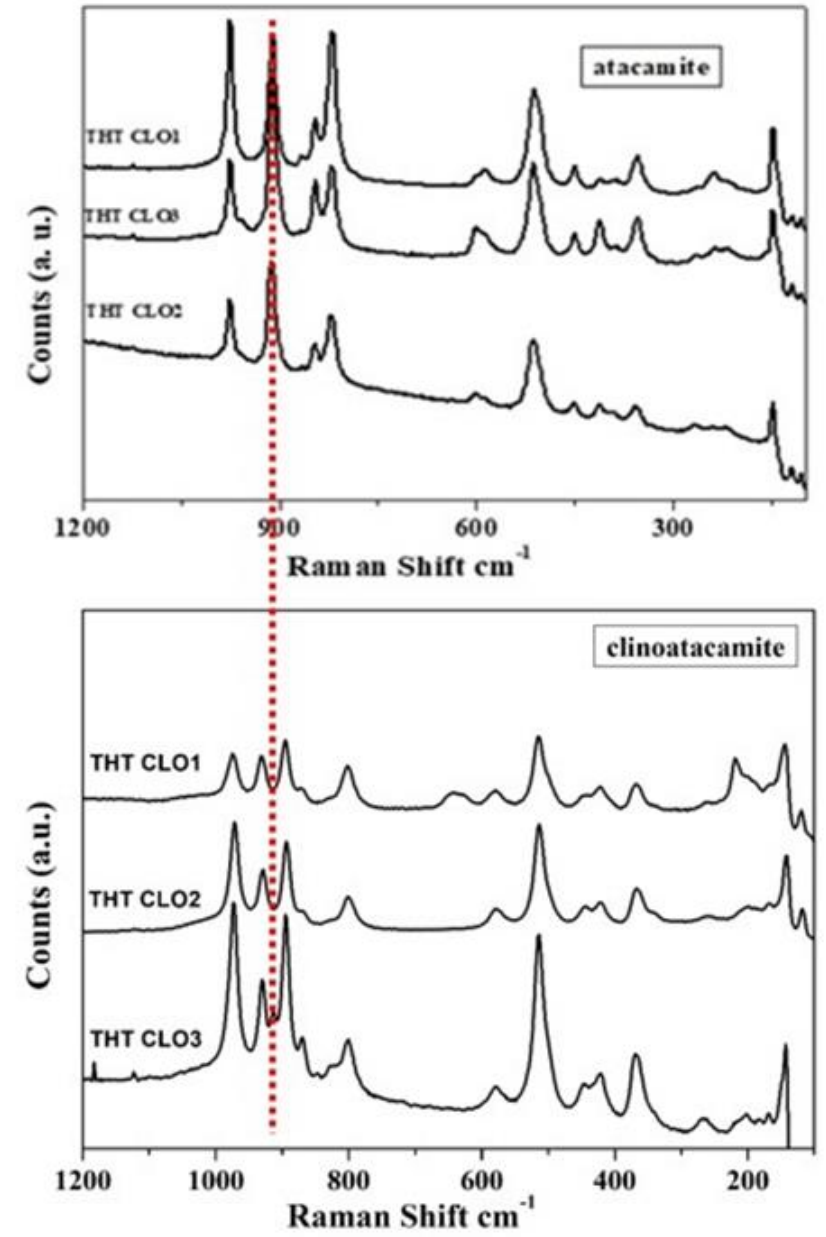

Figure 6. Raman spectra of copper trihydroxychlorides $\left[\mathrm{Cu}_{2} \mathrm{Cl}(\mathrm{OH})_{3}\right]$ atacamite and clinoatacamite on the coins found at Tharros.

phase of the three polymorphs, and botallackite, which forms first, is the least stable. Therefore, when atacamite is found on an archaeological artefact, this indicates the process is in an intermediate stage, while clinoatacamite represents the completion of the sequence [21].

Table 1. Results of vibrational spectra $\left({ }^{*}\right.$ wavenumber $\left./ \mathrm{cm}^{-1}\right)$ and Raman bands attribution of the polymorphs atacamite and clinoatacamite.

\begin{tabular}{ccc}
\hline $\begin{array}{c}\text { atacamite } \\
\mathrm{Cu}_{2} \mathrm{Cl}(\mathrm{OH})_{3}\end{array}$ & $\begin{array}{c}\text { clinoatacamite } \\
\mathrm{Cu}_{2} \mathrm{Cl}(\mathrm{OH})_{3}\end{array}$ & $\begin{array}{c}\text { Raman bands } \\
\text { attribution }\end{array}$ \\
\hline $\mathbf{9 7 5 *}$ & $928^{*}$ & \\
$\mathbf{9 1 0}$ & 893 & hydroxyl deformation \\
$\mathbf{8 4 5}$ & & \\
$\mathbf{8 2 0}$ & 800 & CuO stretching vibration \\
\hline & 580 & \\
\hline $\mathbf{5 1 2}$ & $\underline{513}$ & \\
\hline $\mathbf{4 5 1}$ & 444 & CuCl stretching vibration \\
& 424 & \\
$\mathbf{3 5 4}$ & 365 & \\
$\mathbf{2 3 9}$ & 259 & OCuO bending modes \\
& 200 & \\
\hline $\mathbf{1 4 7}$ & 169 & 142 \\
\end{tabular}

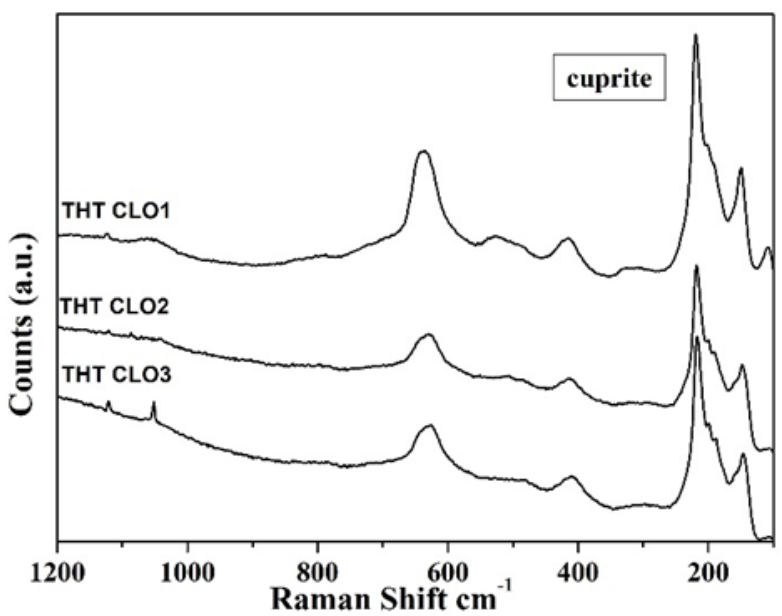

Figure 7. Raman spectra of cuprite $\left(\mathrm{Cu}_{2} \mathrm{O}\right)$ on the coins found at Tharros. The Raman spectra collected in a Cu-rich area evidence the presence of poorly crystallised cuprite.

The nantokite phase, which is very unstable, is the first phase that forms, and it is found as a corrosion product only under dry environmental conditions. From this information, it can be inferred that some corrosion products, such as clinoatacamite, are stable, and therefore, the artefact once excavated will not encounter serious degradation processes. Other products, on the contrary, such as atacamite, change their crystalline structure over time, increasing their volume, for example, and these processes can lead to rapid degradation of the artefact.

The broad bands of the spectra suggest that these minerals have a disordered structure and are not well crystallised.

The cuprite layer, evidenced in the Raman spectra shown in Figure 7 and Table 2, should work as an electrolytic membrane allowing the transport of anions such as $\mathrm{Cl}^{-}$and $\mathrm{O}_{2}^{-}$inside and cations such as $\mathrm{Cu}^{+}$outside. The large amounts of chlorine and oxygen in the interface metal/patina can be interpreted as an autocatalytic reaction that facilitates the oxidation of copper and the accumulation of chloride ions, allowing the formation of cuprite and copper chloride.

It is interesting to observe that the crystal structure of cuprous oxide is still preserved after the incorporation of a small amount of other cations into the lattice. Indeed, the passive layer of $\mathrm{Cu}_{2} \mathrm{O}$ could incorporate up to about 2 at. \% of $\mathrm{Sn}$ into the lattice, forming a defective layer of copper oxide. The substitution of $\mathrm{Cu}$ by $\mathrm{Sn}$ in the $\mathrm{Cu}_{2} \mathrm{O}$ phase is noticeable, as confirmed by the presence of the overtone peak at $218 \mathrm{~cm}^{-1}$. The increase in the intensity of the band indicates that $\mathrm{Cu}_{2} \mathrm{O}$ is disordered and not well crystallised. Furthermore, the presence of Sn, which has replaced some $\mathrm{Cu}$ atoms in the lattice structure, could be linked to a small red shift of the band at $640 \mathrm{~cm}^{-1}$ [22].

The Raman spectrum, shown in Figure 8 and Table 3, highlights the presence of laurionite $[\mathrm{PbCl}(\mathrm{OH})]$, which is related

Table 2. Results of vibrational spectra (wavenumber/ $\mathrm{cm}^{-1}$ ) and Raman bands attribution of cuprite.

\begin{tabular}{cc}
\hline cuprite $\left(\mathrm{Cu}_{2} \mathrm{O}\right)$ & Raman bands attribution \\
\hline$\underline{637}$ & Raman symmetry allowed \\
$\underline{529}$ & Raman symmetry allowed \\
416 & overtone \\
$218^{*}$ & overtone-defective $\mathrm{Cu}_{2} \mathrm{O}^{*}$ \\
$\underline{149}$ & Raman symmetry allowed \\
\hline
\end{tabular}




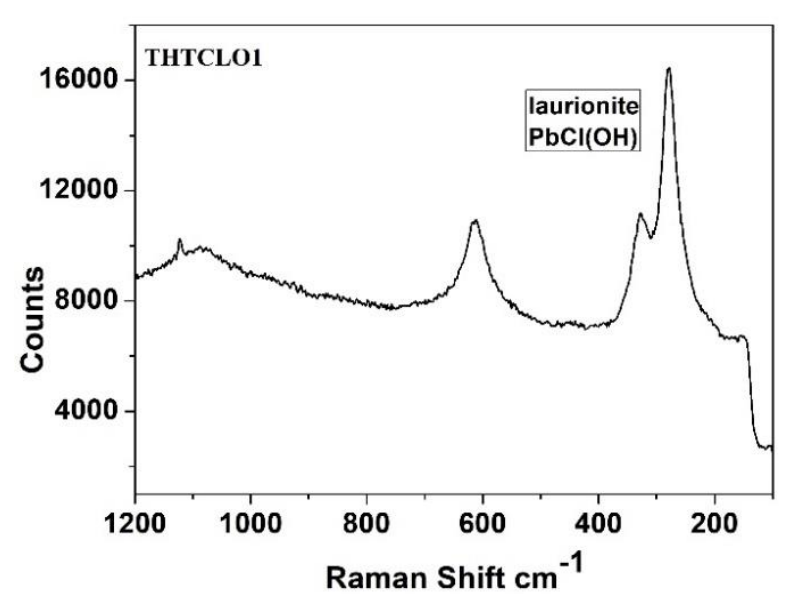

Figure 8. Raman spectrum of laurionite $[\mathrm{PbCl}(\mathrm{OH})]$ on coin THT CLO1.

to the interaction of lead in the alloy with chloride in the soil. Laurionite is a mineral that is thermodynamically stable over a wide range of $\mathrm{pH}$ values and chloride concentrations [24], [24]. Lead was commonly added to bronze in the ancient manufacture of artefacts characterised by low mechanical properties such as coins. Indeed, an addition of lead up to $2 \%$ improves the fluidity of the melted bronze alloy.

Figure 9 and Table 4 show the Raman spectra and bands attribution of aragonite, a polymorph of $\mathrm{CaCO}_{3}$, in the patina of coin THT CLO3. For the calcium carbonate polymorphs, the stability and consequently the solubility increases as follows: amorphous calcium carbonate (ACC) $>$ vaterite $>$ aragonite $>$ calcite [26], [26]. Despite the fact that aragonite is unstable at room temperature and atmospheric pressure, the presence of this mineral is not unusual on $\mathrm{Cu}$ base alloy patinas found in marine and/or coastal environments. This can be due to the formation of microclimates on the surface of the metal with different $\mathrm{pH}$ levels and temperatures and the presence of $\mathrm{Mg}^{2+}$ ions, which are abundant in sea water. Moreover, previous studies have noted that the ratio of $\mathrm{Mg}^{2+}$ to $\mathrm{Ca}^{2+}$ ions in solutions could facilitate the formation of aragonite over calcite [28], [28].

The experimental findings of the adopted multi-analytical approach reveal the deep interaction between soil components and corrosion processes and products and also evidence the relevant presence of chlorides in the patina of the archaeological Cu-based artefacts found in Tharros. This latter occurrence is considered dangerous because it could induce the previously mentioned bronze disease, a cyclic and self-sustaining corrosion reaction of copper that would disfigure the artefact.

These corrosion products have to be neutralised, and their harmful and irreversible actions have to be stopped in order to preserve the artefact [30]-[32].

Several steps can be taken to both prevent and treat bronze disease: i) removing moisture from the artefacts by placing them in the oven on low heat in order to dry them out, with the unwanted possible effect of darkening the surfaces, ii) soaking

Table 3. Results of vibrational spectra (wavenumber/cm-1) and Raman bands attribution of laurionite.

\begin{tabular}{cc}
\hline $\begin{array}{c}\text { laurionite } \\
\mathrm{PbCl}(\mathrm{OH})\end{array}$ & $\begin{array}{c}\text { Raman bands } \\
\text { attribution }\end{array}$ \\
612 & $\mathrm{OH}$ deformation modes \\
327 & $\mathrm{PbCl}$ stretching vibration \\
279 & \\
\hline
\end{tabular}

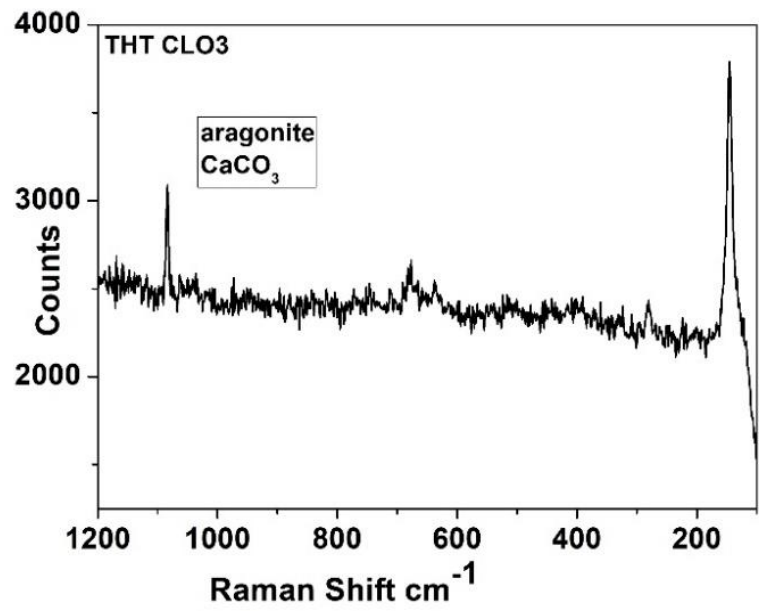

Figure 9. Raman spectrum of aragonite $\left(\mathrm{CaCO}_{3}\right)$ on coin $\mathrm{THT} \mathrm{CLO} 3$.

the artefact in either distilled water or a solution of sodium carbonate and sodium bicarbonate, a non-permanent fix that will only halt the reaction until the cuprous chloride comes into contact with moisture in the air, iii) using corrosion inhibitors such as benzotriazole $\left(\mathrm{C}_{6} \mathrm{H}_{5} \mathrm{~N}_{3}\right)$, a highly carcinogenic complexing agent, or iiii) coating the artefact with a varnish, wax or resin to prevent the recurrence of corrosion; however, if the protective layer lacks adhesion and if the bronze disease hasn't been completely eliminated, the metal will continue to corrode beneath the coating [33]-[36].

Curtailing bronze disease is still an open problem, along with the question of whether humidity control could serve as an alternative method to reversible surface modifications of artefacts. An environmental condition in which relative humidity is maintained below $39 \%$ is ideal for bronze storage and display. However, humidity control is costly and sometimes impractical in a display setting. Consequently, the effects of bronze disease have to be controlled with due precaution, and careful periodic examination of artefacts has to be carried out. To this aim, microRaman spectroscopy has been shown to be a powerful nondestructive tool to characterise the surfaces of archaeological artefacts.

\section{CONCLUSIONS}

By means of $\mu$-Raman spectroscopy, the micro-chemical structure of long-term corrosion products growing on bronze archaeological artefacts found at Tharros was investigated.

Through the multi-analytical approach proposed in this study it was possible to identify the presence of $\mathrm{Cu}(\mathrm{I})$ species such as cuprite $\left(\mathrm{Cu}_{2} \mathrm{O}\right)$ and of copper trihydroxychlorides $\left[\mathrm{Cu}_{2} \mathrm{Cl}(\mathrm{OH})_{3}\right]$ polymorphs. Furthermore, the presence of the hydroxy lead chloride laurionite $[\mathrm{PbCl}(\mathrm{OH})]$ and of the calcium carbonate polymorph aragonite was detected. Taking into account that the artefacts were found in a soil rich in chlorides due to the location

Table 4. Results of vibrational spectra (wavenumber $/ \mathrm{cm}^{1}$ ) and Raman bands attribution of aragonite.

\begin{tabular}{cc}
\hline $\begin{array}{c}\text { aragonite } \\
\mathrm{CaCO}_{3}\end{array}$ & Raman bands attribution \\
\hline 1084 & $\mathrm{C}-\mathrm{O}$ symmetric stretching in $\mathrm{CO}_{3}{ }^{2-}$ \\
\hline 682 & $\mathrm{C}-\mathrm{O}$ asymmetric bending mode in $\mathrm{CO}_{3}{ }^{2-}$ \\
\hline 280 & $\mathrm{Ca}-\mathrm{CO}_{3}{ }^{2-}$ stretching \\
\hline 145 & \\
\hline
\end{tabular}


of the archaeological site along the western coast of Sardinia, it was possible to correlate the corrosion phases to the chemical composition of both the artefacts and the burial context.

The obtained results confirmed that Raman spectroscopy is an effective, versatile and non-invasive technique that allows for the fast detection of mixed polymorphs in the outermost layers of the patina before and after the restoration of the artefact and also during the storage and exhibition period. This is of particular interest in the determination of focused conservation methods for these materials.

In fact, Raman data are an indispensable part of the multianalytical approach adopted for the study of the coins. The high spatial resolution makes it possible to obtain details regarding the physico-chemical interrelationships of mixed phases and corrosion products of a specific metallic artefact - a single micrometric-sized crystal may be analysed. This property is of particular interest in the corrosion field because most of the corrosion products are distributed unevenly on the surface of the artefacts corresponding to localised corrosion formed by holes or craters of micrometric depth.

Indeed, once the corrosion phases have been detected, precautions have to be taken in order to assure the long-lasting preservation of artefacts. According to the authors' knowledge, to achieve this aim, the transformation of dangerous copper chloride or oxy-chlorides into some stable phase is the most suitable approach.

It is worth noting that conservators have developed several procedures to neutralise and stop these degradation processes, ranging from inhibitors to coatings [37]. However, before using a new restoration product, it is necessary to know in advance the way the patina will respond once exposed to the new compounds. A corrosion-inhibiting product must stop the aggressive substances and at the same time preserve the colour and composition of the patina in order to avoid altering the appearance of the archaeological artefact.

\section{ACKNOWLEDGEMENT}

The authors gratefully acknowledge Gianni Chiozzini and Claudio Veroli (ISMN-CNR) for their skilful technical assistance with the SEM and XRD.

\section{REFERENCES}

[1] F. Casadio, C. Daher, L. Bellot-Gurlet, Raman spectroscopy of cultural heritage materials: overview of applications and new frontiers in instrumentation, sampling modalities, and data processing, Topics in Current Chemistry 374(5) (2016), pp. 6269.

DOI: $10.1007 / \mathrm{s} 41061-016-0061-\mathrm{z}$

[2] I. Martina, R. Wiesinger, M. Schreiner, Micro-Raman investigations of early stage silver corrosion products occurring in sulfur containing atmospheres, Raman Spectrosc. 44 (2013), pp. $770-775$.

DOI: $\underline{10.1002 / j \mathrm{js} .4276}$

[3] O. Berger, P. B. Yersin, J. M. B. Yersin, C. Hartman, E. Hildbrand, V. Hubert, K. Hunger, M. Ramstein, M. Worle, Applications of micro-Raman spectroscopy in cultural heritage examples from the Laboratory for Conservation Research of the Collections Centre of the Swiss National Museums, CHIMIA 62(11) (2008), pp. 882-886.

DOI: $10.2533 /$ chimia. 2008.882

[4] T. de Caro, The ancient metallurgy in Sardinia (Italy) through a study of pyrometallurgical materials found in the archaeological sites of Tharros and Montevecchio (West Coast of Sardinia), J.
Cult. Herit. 28 (2017), pp. 65-74

DOI: $10.1016 /$ j.culher.2017.05.016

[5] S. Balmuth, R. F. Tylecote, Ancient copper and bronze in Sardinia: excavation and analyses, J. Field Archaeol. 3 (1976), pp. 195-210. DOI: $10.1179 / 009346976791490853$

[6] A. Mezzi, E. Angelini, C. Riccucci, S. Grassini, T. de Caro, F. Faraldi, P. Bernardini, Micro-structural and micro-chemical composition of bronze artefacts from Tharros (Western Sardinia, Italy), Surf. Interface Anal. 44 (2012), pp. 958-962.

DOI: $10.1002 /$ sia. 4804

[7] T. de Caro, D. Caschera, G. M. Ingo, P. Calandra, Micro-Raman innovative methodology to identify $\mathrm{Ag}-\mathrm{Cu}$ mixed sulphides as tarnishing corrosion products, J. Raman Spectrosc. 47(7) (2016), pp. 852-859.

DOI: $10.1002 /$ irs.4900

[8] E. Angelini, A. Batmaz, T. de Caro, F. Faraldi, S. Grassini, G. Ingo, C. Riccucci, The role of surface analysis in the strategies for conservation of metallic artefacts from the Mediterranean Basin, Surf. Interface Anal. 46 (2014), pp. 754-763.

DOI: $10.1002 / \mathrm{sia} .5512$

[9] M. Buchard, D. C. Smith, Catalogue of 45 reference Raman spectra of minerals concerning research in art history or archaeology, especially on corroded metals and coloured glass, Spectrochim. Acta A 59(10) (2003), pp. 2247-2266. DOI: $10.1016 / \mathrm{S} 1386-1425(03) 00069-6$

[10] D. A. Scott, Metallography and Microstructure of Ancient and Historic Metals, The J. Paul Getty Conservation Institute, Malibu, U.S.A., 1991 ISBN 0-89236-195-6.

[11] L. Es Sebar, L. Iannucci, Y. Goren, P. Fabian, E. Angelini, S. Grassini, Non-invasive characterization of ancient Cu-based coins using Raman spectroscopy, 2019 IMEKO TC4 International Conference on Metrology for Archaeology and Cultural Heritage, MetroArchaeo 2019, Florence, Italy, December 4-6, 2019, pp. 389-394. Online [Accessed 20 march 2021] https://www.imeko.org/publications/tc4-Archaeo2019/IMEKO-TC4-METROARCHAEO-2019-77.pdf

[12] M. Bouchard, D. C. Smith, Evaluating Raman microscopy for the non-destructive archaeometry of corroded coins: a powerful technique for conservation studies, Asian Chemistry Letters 5(3) (2001), pp. 157-170.

[13] R. L. Frost, P. A. Williams, Raman and infrared spectroscopic study of the basic copper chloride minerals - implications for the study of the copper and brass corrosion and 'bronze disease', N. Jb. Miner. Abh. 178(2) (2003), pp. 197-215.

DOI: $\underline{10.1127 / 0077-7757 / 2003 / 0178-0197}$

[14] G. L. Fox, Cupreous metal corrosion at a Bronze Age coastal marine archaeological site: a study of site processes at Tel Nami, Israel, Int. J. Naut. Archaeol. 23(1) (1994), pp. 41-47.

DOI: $\underline{10.1111 / j .1095-9270.1994 . t b 00440 . x}$

[15] G. Ingo, E. Angelini, T. de Caro, G. Bultrini, I. Calliari, Combined use of GDOES, SEM + EDS, XRD and OM for the microchemical study of the corrosion products on archaeological bronzes, Appl. Phys. A 79 (2004), pp. 199-203.

DOI: $10.1007 / \mathrm{s} 00339-004-2533-1$

[16] D. A. Scott, Bronze disease: a review of some chemical problems and the role of relative humidity, JAIC 33 (1994), pp. 1-23. DOI: $10.1179 / 019713690806046064$

[17] G. Ingo, T. de Caro, C. Riccucci, E. Angelini, S. Grassini, S. Balbi, P. Bernardini, D. Salvi, L. Bousselmi, A. Çilingiroglu, M. Gener, V. Gouda, O. Al-Jarrah, S. Khosroff, Z. Mahdjoub, Z. Al saad, W. El-Saddik, P. Vassiliou, Large scale investigation of chemical composition, structure and corrosion mechanism of bronze archaeological artefacts from Mediterranean basin, Appl. Phys. A 83 (2006), pp. 513-520.

DOI: $10.1007 / \mathrm{s} 00339-006-3550-\mathrm{z}$

[18] L. Robbiola, J. M. Blengino, C. Fiaud, Morphology and mechanisms of formation of natural patinas on archaeological Cu-Sn alloys, Corros. Sci. 40 (1998), pp. 20-83. 
[19] M. Quaranta, I. Sandu, Micro-stratigraphy of copper-based archaeological objects: description of degradation mechanisms by means of an integrated approach, Proc. of $9^{\text {th }}$ Int. Conference on NDT of Art, Jerusalem, Israel, 25-30 May 2008, pp. 1-8. Online [acessed 20 March 2021] https://www.ndt.net/search/docs.php3?id=6154

[20] N. Montoya, E. Montagna, Y. Lee, M. T. Doménech-Carbó, A. Doménech-Carbó, Raman spectroscopy characterization of 10cash productions from the late Chinese emperors to the Republic, J Raman Spectrosc. 48 (2017), pp. 1337-1345. DOI: $10.1002 /$ jrs. 5218

[21] V. Bongiorno, S. Campodonico, R. Caffara, P. Piccardoa, M. M. Carnascialia, Micro-Raman spectroscopy for the characterization of artistic patinas produced on copper-based alloys, J. Raman Spectrosc. 43 (2012), pp. 1617-1622.

DOI: $10.1002 /$ jrs. 4167

[22] F. Di Turo, C. De Vito, F. Coletti, F. Mazzei, R. Antiochia, G. Favero, A multi-analytical approach for the validation of a jellified electrolyte: application to the study of ancient bronze patina, Microchem. J. 134 (2017), pp. 154-163. DOI: $10.1016 /$ i.microc.2017.05.015

[23] R. L. Frost, W. Martens, J. T. Kloprogge, P. A. Williams, Raman spectroscopy of the basic copper chloride minerals atacamite and paratacamite: implications for the study of copper, brass and bronze objects of archaeological significance, J. Raman Spectrosc. 33 (2002), pp. 801-806.

DOI: $10.1002 /$ jrs. 921

[24] R. L. Frost, P. A. Williams, Raman spectroscopy of some basic chloride containing minerals of lead and copper, Spectrochim. Acta A 60 (2004), pp. 2071-2077.

DOI: $10.1016 /$ i.saa.2003.11.007

[25] S. V. Krivovichev, F. C. Hawthorne, P. A. Williams, Structural complexity and crystallization: the Ostwald sequence of phases in the $\mathrm{Cu}_{2}(\mathrm{OH})_{3} \mathrm{Cl}$ system (botallackite-atacamite-clinoatacamite), Struct. Chem. 28 (2017), pp. 153-159. DOI: $10.1007 / \mathrm{s} 11224-016-0792-z$

[26] F. Ospitali, C. Chiavari, C. Martini, E. Bernardi, F. Passarini, L. Robbiola, The characterization of Sn-based corrosion products in ancient bronzes: a Raman approach, J. Raman Spectrosc. 43 (2012), pp. 1596-1603. DOI: $\underline{10.1002 / \text { irs. } 4037}$

[27] L. Burgio, R. J. H. Clark, S. Firth, Raman spectroscopy as a means for the identification of plattnerite $\left(\mathrm{PbO}_{2}\right)$, of lead pigments and of their degradation products, Analyst 126 (2001), pp. 222-227. DOI: $10.1039 /$ b008302j

[28] R. L. Frost, W. Martens, J. T. Kloprogge, Z. Ding, Raman spectroscopy of selected lead minerals of environmental significance, Spectrochim. Acta A 59 (2003), pp. 2705-2711. DOI: $10.1016 / \mathrm{s} 1386-1425(03) 00054-4$

[29] M. De La Pierre, C. Carteret, L. Maschio, E. André, R. Orlando, R. Dovesi, The Raman spectrum of $\mathrm{CaCO}_{3}$ polymorphs calcite and aragonite: a combined experimental and computational study, J. Chem. Phys. 140 (2014), pp. 164509-164519. DOI: $10.1063 / 1.4871900$

[30] N. Buzgar, A. Apopei, The Raman study of certain carbonates, Anal. Şt. Univ. “Al. I. Cuza” Iaşi LV, 2 (2009), pp. 97-112.

[31] W. Suna, S. Jayaramana, W. Chenb, K. A. Persson, G. Cedera, Nucleation of metastable aragonite $\mathrm{CaCO}_{3}$ in seawater, PNAS 112(11) (2015), pp. 3199-3204.

DOI: $\underline{10.1073 / \text { pnas. } 1423898112}$

[32] R. L. Frost, Raman spectroscopy of selected copper minerals of significance in corrosion, Spectrochim. Acta A 59(6) (2003), pp. 1195-1204.

DOI: $10.1016 / \mathrm{s} 1386-1425(02) 00315-3$

[33] F. Faraldi, B. Cortese, D. Caschera, G. Di Carlo, C. Riccucci, T. de Caro, G. M. Ingo, Smart conservation methodology for the preservation of copper-based objects against the hazardous corrosion, Thin Solid Films 622 (2017), pp. 130-135.

DOI: $10.1016 /$ i.tsf.2016.12.024

[34] D. Scott, Bronze disease: a review of some chemical problems and the role of relative humidity, The Journal of the American Institute for Conservation 29(2) (1990), Article 7.

DOI: $10.1179 / 019713690806046064$

[35] A. Dermai, D. Chebabe, M. Doubi, H. Erramli, N. Hajjaji, M. P. Casaletto, G. Ingo, C. Riccucci, T. de Caro, Inhibition of bronze corrosion in $3 \% \mathrm{NaCl}$ media by novel non-toxic 3-phenyl-1,2,4triazole thione formulation, Corros. Eng. Sci. Technol. 50 (2014), pp. 128-136.

[36] F. Faraldi, E. Angelini, D. Caschera, A. Mezzi, C. Riccucci, T. de Caro, Diamond-like carbon coatings for the protection of metallic artefacts: effect on the aesthetic appearance, Appl. Phys. A 114 (2014), pp. 663-671. DOI: $10.1007 / \mathrm{s} 00339-013-8171-8$

[37] M. Abel, A. Carley, J. Watts, A. Mezzi, E. Angelini, T. de Caro, S. Grassini, F. Faraldi, C. Riccucci, G. Ingo, Investigation of the benzotriazole inhibition mechanism of bronze disease, Surf. Interface Anal. 44 (2012), pp. 968-971.

DOI: $\underline{10.1002 / \text { sia. } 4841}$

[38] L. Iannucci, J. F. Rios-Rojas, E. Angelini, M. Parvis, S. Grassini, Electrochemical characterization of innovative hybrid coatings for metallic artefacts, Eur. Phys. J. Plus 133:522 (2018), pp. 1-7. DOI: $10.1140 /$ epip/i2018-12368-3 